\title{
Developing Instrument to Measure Elementary School Teachers' Professional Ethics in Indonesia
}

\author{
Eva Dwi Kumala Sari, STIT Al-Marhalah Al-'Ulya, Indonesia, eva@almarhalah.ac.id \\ Ilham Falani*, Universitas Indraprasta PGRI Jakarta, Indonesia, ilhamfalani@gmail.com \\ *Corresponding Author
}

\begin{abstract}
This study aims to develop an instrument to measure elementary school teachers' professional ethics in Indonesia. The instrument was developed from the Yael Fishers' instrument. The instrument's validity in this study was analysed using the Confirmatory Factor Analysis (CFA) method with the M-Plus software. The sample of this study consisted of 437 elementary school teachers in Jakarta, Indonesia. The analysis results show that the teacher professional ethics instrument's factor loading coefficient has a significant $t$ value $(t>1.96)$. The results also showed a factor model that was fit with Chi-square = $3443.779 *, \mathrm{df}=1221, \mathrm{P}$-value $=0.0000, \mathrm{RMSEA}=0.065$, and CFI $=0.908$. Based on the results, it can be concluded that the items in the teachers' professional ethics instrument developed can measure defined constructs properly.
\end{abstract}

Keywords: Profession Ethics, Elementary School, CFA

Received: 04.12.2020 Accepted: 19.01.2021 $\quad$ Published: 03.02.2021

\section{INTRODUCTION}

The role of teachers is increasingly important in the globalization era. Through coaching carried out by professional teachers, students can become qualified, competitive, and productive human resources as national assets in facing global competition. Teachers' duties and responsibilities are not easy because they have to go through a long process and full of various demands.

Ethics and teaching are two things that are related. Curtis (2006) defines ethics as a "principle of right and wrong behavior and decisions." Kasher (1993) defines "ethics" as moral values that govern an individual or group's appropriate behavior. Banks (2003) argues that professional teaching ethics is a set of teachers' beliefs regarding relationships with all teacher life stakeholders. These principles form the basis for teachers in their daily activities at work.

Furthermore, Campbell (2008) defines teaching as a moral profession. The relationship between ethics and teacher professional practice is often overlooked. Campbell (2008), Dewey (1909), Waller (1932), and Peter (1966) said that teacher education tends to focus on discussing moral dimensions in a curricular context. Teacher education does not examine the moral dimensions of teaching as responsibility, ethical roles, and teacher practices.

Profession ethics is an important role in the education system to create mutual understanding between teachers and other related parties. There are several principles in some developed countries for teachers in the education system called "Professional Ethics" (Ashraf, 2015). Professional ethics is a standard of professional behavior that helps determine what good and bad standards in a profession (Urbanc, 2009; Corney et al., 1998; Izrael \& Zohar, 2002) are. A code of ethics is usually a written document produced by a professional association, occupational regulatory body, or other professional body to guide practitioners, protect service users, and safeguard their reputation (Torda, 2004). Teachers' professional ethics concerns the norms, values, and principles that must govern educators' professional behavior. It emphasizes the normative meaning inherent in determining the appropriateness of professional practice. It is important to assess teachers' professional ethics in schools (Husu, 2003; Tood, 2001).

Violating the professional code of ethics for teachers can be defined as deviations from the moral norms in the code of ethics relating to teachers' profession. Violations can be in the form of minor, moderate, to severe violations. Every teacher who violates the code of ethics will get sanctions by the applicable laws and regulations.

Violations of the code of ethics are very common among teachers, without exception in Indonesia. Many cases of teacher convictions have occurred. The number of these cases is due to parents' reports about allegations of violence committed by teachers in applying discipline when educating students. Moreover, incidences of sexual abuse among children in schools tend to increase, especially in Indonesia. 
A survey conducted by the Indonesian Child Protection Commission (KPAI) showed that $87.6 \%$ of 1,000 students from elementary to high school levels in nine provinces in Indonesia had experienced sexual harassment, and $29.9 \%$ of the perpetrators were their teachers (Kompas, 2012). According to Shapiro \& Stefkovich (2011), this phenomenon could happen in education because the teacher profession, unlike other professions, required them to complete professional ethics education before graduation. Teachers' profession does not have rational ethical and empirical education to enhance their ethical behavior. Besides, teachers are directly involved in educating students' moral character. Therefore, a teacher must have good professional ethics to be an example for their students. Therefore, it is important to develop an instrument to measure the ethical value of the teaching profession.

According to Melgosa (2012), there is a need for policies that guide teachers' moral behavior. It is difficult to deny that all teachers are directly involved in educating students' moral character and ethical value systems in a society. Also, parents expect their children to be educated with certain standards such as honesty and fairness (Carr \& London, 2000).

The above cases show that there are still many violations of the code of ethics committed by teachers. The teachers' ethics code in Indonesia started to be implemented on January 1, 2013 (Vivanews, 2012). Although it has been implemented for a long time, many violations are done by the teachers in Indonesia. Through the Teacher Professional Honorary Board, which controls the code of ethics, there must be a standardized tool for measuring teachers' professional ethics in Indonesia. The juridical basis for the code of ethics for teachers in Indonesia was formulated by the Indonesian Teachers Association (PGRI) through the XIII PGRI Congress in 1973. Through professional organizations, the Teacher Code of Ethics can be applied to control and maintain teacher behavior, which will ensure teachers' quality, especially in moral matters. In 2008, the Teachers Association of the Republic of Indonesia (PGRI), a teacher organization, developed a teacher code of ethics, but it has not yet created an appropriate measuring tool to measure the professional ethics of teachers, so there are still many violations of the code of ethics committed by teachers in Indonesia. (Astuti, 2012). Research related to measuring the teachers' professional ethics in Indonesia is still not widely conducted.

Based on the explanation above, it is necessary to conduct research on the development of instruments to measure teacher professional ethics. So the instrument can be used in controlling the professional ethics of teachers in Indonesia. By knowing the teacher's ethics code, the Teacher Professional Honorary Board can take quick action through preventive measures and training that can foster teacher professional ethics for the better.

\section{METHODS}

The development of this environmental literacy instrument uses the Research and Development (R\&D) method. According to Borg and Gall (1983), "R\&D method is a process used to develop and validate educational products. The steps of this process are usually referred to as the R \& D cycle, which consists of studying research findings pertinent to the product to be developed, developing the products based on these findings, field testing it in the setting where it will be used eventually, and revising it to correct the deficiencies found in the filed-testing stage. This research was conducted in several stages; according to Haladyna (2004), research in the field of instrument development consists of three main stages, 1) developing instruments, 2) testing instruments, and 3) selecting items for administering instruments. In detail, the development of teaching professional ethics instruments is made through the following stages:

1. Develop conceptual and operational definitions of the variables of teacher profession ethics.

2. Compile dimensions and indicators based on the concepts developed.

3. Arrange Likert scale statement items based on the grid that has been made

4. Experts assess the instrument that has been made. The assessment by experts is carried out qualitatively and quantitatively. In this study, the quantitative analysis of the experts' assessment used the C H Lawshe Content Validity Ratio (CVR) validity test and the C. Hoyt reliability test to determine the expert's assessment of the accuracy and clarity of the instrument items.

5. Revising instrument items based on advice from experts

6. Empirical trials on teachers to see the feasibility and readability of the instrument

7. First phase trial (small sample size)

8. Constructed validity test of the instrument based on results of the first trial using CFA with M-Plus software helps determine the extent to which each variable can be explained by each dimension (Umar, 2014). CFA. procedure; (a) testing the hypothesis: Do all items measure one defined construct? (b) does each item yield significant information about the construct being measured? Through CFA., researchers will determine which items are valid and which items will be dropped. There are three categories of items categorized as good in the CFA.: (1) if the value of $t<1.96$, then 
the items must be dropped, and if $t>1.96$, then the item is valid. (2) see the positive or negative factor loading; if the factor loading is negative, the item must be dropped. Meanwhile, if the loading factor is positive, the items are accepted. (Umar, 2012a).

9. Instrument improvement based on the results of the first phase trial analysis

10. Second phase empirical trial (large sample size)

11. Constructed validity test of the instrument based on the results of the second trial using CFA. with MPlus software helps determine the extent to which each dimension can explain each variable.

12. Administering the instrument in standard form accompanied by a manual

This study's sample was elementary school teachers in four administrative cities of DKI Jakarta Province, Indonesia. Determination of the sample used by using cluster random sampling technique. The sample size used refers to Galbe and Wolf (1993), which states that the sample size can be determined based on seven times the number of items, so the sample size in this study is 437 respondents.

\section{RESULTS}

Based on the results of the study on the development of professional ethics test instruments and suggestions from experts, the dimensions and indicators of teacher profession ethics that are suitable for conditions in Indonesia are obtained as the following table:

Table 1. Grids for the Development of Professional Ethics Test Instruments for Teachers in Indonesia

\begin{tabular}{|c|c|c|c|}
\hline No. & Dimensions & Indicators & Item Number \\
\hline \multirow[t]{10}{*}{1} & \multirow[t]{10}{*}{ Personal value } & 1.1 Personal Promise & $1,2,3$ \\
\hline & & 1.2 Public Promise & $4,5,6$ \\
\hline & & 1.3 Soul calling & 7.8 \\
\hline & & 1.4 commitment & 9 \\
\hline & & 1.5 caring & 10 \\
\hline & & 1.6 Empathy & 11 \\
\hline & & 1.7 Justice & 12 \\
\hline & & 1.8 Respect & 13.14 \\
\hline & & 1.9 Responsibility & $15,16,17,18$ \\
\hline & & 1.10 Special skills & $19,20,21,22,23,24,25,26,27$ \\
\hline \multirow[t]{5}{*}{2} & \multirow[t]{5}{*}{ Social Value } & 2.1 Protects society & 28,29 \\
\hline & & 2.2 Serving the society & $30,31,32$ \\
\hline & & 2.3 Social responsibility & $33,34,35$ \\
\hline & & 2.4 Dedication & $\begin{array}{c}36,37,38,3940,41,42,43,44, \\
45,46,47\end{array}$ \\
\hline & & 2.5 peers & 48,49 \\
\hline \multirow[t]{4}{*}{3} & \multirow[t]{4}{*}{ Universal Value } & 3.1 Communication & $50,51,52$ \\
\hline & & 3.2 Cooperation & $53,54,55$ \\
\hline & & $\begin{array}{l}\text { 3.3 Professional } \\
\text { Development }\end{array}$ & $56,57,58$ \\
\hline & & 3.4 Profession & $59,60,61,62,63,64$ \\
\hline
\end{tabular}

In the table above, it can be seen that the variable dimensions of teacher professional ethics are divided into three parts. Each dimension is represented by indicators and statement items with a certain number. There were 64 statement items at the beginning of the instrument's preparation, then the instrument was assessed by experts.

\section{Content Validity and Reliability}

The quantitative analysis of the experts' assessments can be seen in the table below 
Tabel 2. Tabulation of Panelist Assessment Score CVR

\begin{tabular}{|c|c|c|}
\hline Items & Index ratio CVR & Item Status \\
\hline Item 1 & 0.900 & Valid \\
\hline Item 2 & 0.700 & Valid \\
\hline Item 3 & 0.700 & Valid \\
\hline Item 4 & 1 & Valid \\
\hline Item 5 & 1 & Valid \\
\hline Item 6 & 0.400 & Drop \\
\hline Item 7 & 0.900 & Valid \\
\hline Item 8 & 1 & Valid \\
\hline Item 9 & 0.600 & Valid \\
\hline Item 10 & 0.800 & Valid \\
\hline Item 11 & 1 & Valid \\
\hline Item 12 & 0.400 & Drop \\
\hline Item 13 & 0.800 & Valid \\
\hline Item 14 & 0.800 & Valid \\
\hline Item 15 & 0.900 & Valid \\
\hline Item 16 & 0.600 & Valid \\
\hline Item 17 & 0.700 & Valid \\
\hline Item 18 & 0.800 & Valid \\
\hline Item 19 & 0.900 & Valid \\
\hline Item 20 & 0.600 & Valid \\
\hline Item 21 & 0.900 & Valid \\
\hline Item 22 & 0.700 & Valid \\
\hline Item 23 & 0.400 & Drop \\
\hline Item 24 & 0.70 & Valid \\
\hline Item 25 & 0.90 & Valid \\
\hline Item 26 & 1 & Valid \\
\hline Item 27 & 1 & Valid \\
\hline Item 28 & 0.700 & Valid \\
\hline Item 29 & 1 & Valid \\
\hline Item 30 & 1 & Valid \\
\hline Item 31 & 0.800 & Valid \\
\hline Item 32 & 0.100 & Drop \\
\hline Item 33 & 0.900 & Valid \\
\hline Item 34 & 1 & Valid \\
\hline Item 35 & 0.700 & Valid \\
\hline Item 36 & 0.700 & Valid \\
\hline Item 37 & 0.800 & Valid \\
\hline Item 38 & 0.600 & Valid \\
\hline Item 39 & 0.700 & Valid \\
\hline Item 40 & 0.900 & Valid \\
\hline Item 41 & 0.500 & Drop \\
\hline Item 42 & 0.900 & Valid \\
\hline Item 43 & 1 & Valid \\
\hline Item 44 & 0.600 & Valid \\
\hline Item 45 & 0.900 & Valid \\
\hline Item 46 & 0.800 & Valid \\
\hline Item 47 & 0.900 & Valid \\
\hline Item 48 & 0.700 & Valid \\
\hline Item 49 & 0.900 & Valid \\
\hline Item 50 & 0.700 & Valid \\
\hline Item 51 & 0.600 & Valid \\
\hline Item 52 & 0.900 & Valid \\
\hline Item 53 & 1 & Valid \\
\hline Item 54 & 0.800 & Valid \\
\hline
\end{tabular}




\begin{tabular}{ccc}
\hline Items & Index ratio CVR & Item Status \\
\hline Item 55 & 1 & Valid \\
\hline Item 56 & 0.600 & Valid \\
\hline Item 57 & 0.500 & Drop \\
\hline Item 58 & 0.900 & Valid \\
\hline Item 59 & 0.900 & Valid \\
\hline Item 60 & 0.600 & Valid \\
\hline Item 61 & 0.800 & Valid \\
\hline Item 62 & 0.900 & Valid \\
\hline Item 63 & 0.700 & Valid \\
\hline Item 64 & 0.600 & Valid \\
\hline
\end{tabular}

Based on the quantitative results of the experts' assessment using CVR, it was obtained 61 items were declared valid, and three items were dropped. An Item is declared valid if there is a matching value among expert assessments above 0.50. The expert assessment quantitatively uses the C. Hoyt reliability test to determine the experts' assessment of the instrument items' accuracy and clarity. The reliability value of the test instrument is 0.953 , high-reliability category. It means that the items designed are considered steady in measuring the specified variables (Susetyo, 2015).

\section{Constructed Validity}

The test construct validity test is carried out in two stages. The first stage of construct validity was tested on a small sample size of 178 respondents. Based on the first stage construct validity test results, it was found that out of the 64 items tested, 3 items did not meet the criteria, namely the loading factor $t<1.96$. After that, the three items were dropped. The following is the item number dropped. The second stage of the construct validity test was carried out on a large sample of 437 respondents. Based on the CFA results using the M.Plus 7.0 software, the results showed that the items had met the validity criteria. These results can be seen in the table below:

Table 3. Summary of First And Second Stage CFA. Results

\begin{tabular}{|c|c|c|c|c|c|c|c|c|}
\hline No & Dimensions & Items & $\begin{array}{l}\text { Loading } \\
\text { Factor } \\
\text { Trial } 1\end{array}$ & $\begin{array}{l}\text { Attenuation } \\
\text { Effect }\end{array}$ & Status & $\begin{array}{c}\text { Loading } \\
\text { Factor } \\
\text { Trial } 2\end{array}$ & $\begin{array}{l}\text { Attenuation } \\
\text { Effect }\end{array}$ & Status \\
\hline 1 & \multirow{18}{*}{$\begin{array}{l}\text { Personal } \\
\text { Value }\end{array}$} & $\mathrm{A} 1$ & 0,767 & 0,896 & Valid & 0,629 & 0,660 & Valid \\
\hline 2 & & $\mathrm{~A} 2$ & 0,816 & 0,953 & Valid & 0,687 & 0,721 & Valid \\
\hline 3 & & A3 & 0,841 & 0,982 & Valid & 0,723 & 0,759 & Valid \\
\hline 4 & & A4 & 0,612 & 0,715 & Valid & 0,539 & 0,566 & Valid \\
\hline 5 & & A5 & 0,755 & 0,882 & Valid & 0,674 & 0,707 & Valid \\
\hline 6 & & $\mathrm{~A} 6$ & 0,454 & 0,530 & Valid & - & \#VALUE! & Drop \\
\hline 7 & & A7 & 0,593 & 0,693 & Valid & 0,611 & 0,641 & Valid \\
\hline 8 & & A8 & 0,533 & 0,623 & Valid & - & \#VALUE! & Drop \\
\hline 9 & & A9 & 0,663 & 0,774 & Valid & 0,497 & 0,522 & Valid \\
\hline 10 & & $\mathrm{~A} 10$ & 0,529 & 0,618 & Valid & 0,709 & 0,744 & Valid \\
\hline 11 & & A11 & 0,852 & 0,995 & Valid & 0,752 & 0,789 & Valid \\
\hline 12 & & A12 & 0,598 & 0,698 & Valid & 0,724 & 0,760 & Valid \\
\hline 13 & & A13 & 0,799 & 0,933 & Valid & 0,714 & 0,749 & Valid \\
\hline 14 & & A14 & 0,789 & 0,922 & Valid & 0,782 & 0,821 & Valid \\
\hline 15 & & A15 & $-0,114$ & $-0,133$ & Drop & 0,675 & 0,708 & Valid \\
\hline 16 & & A16 & 0,66 & 0,771 & Valid & 0,621 & 0,652 & Valid \\
\hline 17 & & A17 & 0,849 & 0,992 & Valid & 0,618 & 0,649 & Valid \\
\hline 18 & & A18 & $-0,408$ & $-0,477$ & Drop & 0,671 & 0,704 & Valid \\
\hline
\end{tabular}




\begin{tabular}{|c|c|c|c|c|c|c|c|c|}
\hline No & Dimensions & Items & $\begin{array}{l}\text { Loading } \\
\text { Factor } \\
\text { Trial } 1\end{array}$ & $\begin{array}{l}\text { Attenuation } \\
\text { Effect }\end{array}$ & Status & $\begin{array}{c}\text { Loading } \\
\text { Factor } \\
\text { Trial } 2\end{array}$ & $\begin{array}{l}\text { Attenuation } \\
\text { Effect }\end{array}$ & Status \\
\hline 19 & & A19 & 0,667 & 0,779 & Valid & 0,714 & 0,749 & Valid \\
\hline 20 & & A20 & 0,805 & 0,940 & Valid & 0,779 & 0,818 & Valid \\
\hline 21 & & $\mathrm{~A} 21$ & 0,787 & 0,919 & Valid & 0,773 & 0,811 & Valid \\
\hline 22 & & A22 & 0,66 & 0,771 & Valid & 0,622 & 0,653 & Valid \\
\hline 23 & & A23 & 0,567 & 0,662 & Valid & 0,753 & 0,790 & Valid \\
\hline 24 & & A24 & 0,711 & 0,830 & Valid & - & \#VALUE! & Drop \\
\hline 25 & & A25 & 0,789 & 0,922 & Valid & 0,364 & 0,382 & Valid \\
\hline 26 & & A26 & 0,521 & 0,609 & Valid & 0,758 & 0,795 & Valid \\
\hline 27 & & A27 & 0,517 & 0,604 & Valid & 0,78 & 0,819 & Valid \\
\hline 28 & \multirow{22}{*}{$\begin{array}{l}\text { Social } \\
\text { Value }\end{array}$} & B28 & 0,65 & 0,759 & Valid & 0,782 & 0,821 & Valid \\
\hline 29 & & B29 & 0,764 & 0,892 & Valid & 0,688 & 0,722 & Valid \\
\hline 30 & & B30 & 0,499 & 0,583 & Valid & - & \#VALUE! & Drop \\
\hline 31 & & B31 & 0,431 & 0,503 & Valid & 0,673 & 0,706 & Valid \\
\hline 32 & & B32 & 0,747 & 0,873 & Valid & 0,811 & 0,851 & Valid \\
\hline 33 & & B33 & 0,376 & 0,439 & Valid & 0,702 & 0,737 & Valid \\
\hline 34 & & B34 & 0,721 & 0,842 & Valid & 0,76 & 0,798 & Valid \\
\hline 35 & & B35 & $-0,268$ & $-0,313$ & Drop & 0,73 & 0,766 & Valid \\
\hline 36 & & B36 & 0,418 & 0,488 & Valid & - & \#VALUE! & Drop \\
\hline 37 & & B37 & 0,805 & 0,940 & Valid & 0,76 & 0,798 & Valid \\
\hline 38 & & B38 & 0,698 & 0,815 & Valid & 0,864 & 0,907 & Valid \\
\hline 39 & & B39 & 0,222 & 0,259 & Valid & 0,648 & 0,680 & Valid \\
\hline 40 & & B40 & 0,864 & 1,009 & Valid & - & \#VALUE! & Drop \\
\hline 41 & & B41 & 0,863 & 1,008 & Valid & 0,502 & 0,527 & Valid \\
\hline 42 & & B42 & 0,775 & 0,905 & Valid & 0,445 & 0,467 & Valid \\
\hline 43 & & B43 & 0,28 & 0,327 & Valid & 0,497 & 0,522 & Valid \\
\hline 44 & & B44 & 0,485 & 0,566 & Valid & - & \#VALUE! & Drop \\
\hline 45 & & B45 & 0,385 & 0,450 & Valid & 0,615 & 0,645 & Valid \\
\hline 46 & & B46 & 0,565 & 0,660 & Valid & - & \#VALUE! & Drop \\
\hline 47 & & B47 & 0,218 & 0,255 & Valid & 0,724 & 0,760 & Valid \\
\hline 48 & & B48 & 0,51 & 0,596 & Valid & - & \#VALUE! & Drop \\
\hline 49 & & B49 & 0,137 & 0,160 & Valid & 0,431 & 0,452 & Valid \\
\hline 50 & \multirow{8}{*}{$\begin{array}{l}\text { Universal } \\
\text { Value }\end{array}$} & $\mathrm{C} 50$ & 0,667 & 0,779 & Valid & 0,614 & 0,644 & Valid \\
\hline 51 & & C51 & 0,215 & 0,251 & Valid & 0,72 & 0,756 & Valid \\
\hline 52 & & C52 & 0,656 & 0,766 & Valid & - & \#VALUE! & Drop \\
\hline 53 & & C53 & 0,58 & 0,677 & Valid & 0,793 & 0,832 & Valid \\
\hline 54 & & C54 & 0,815 & 0,952 & Valid & 0,795 & 0,834 & Valid \\
\hline 55 & & C55 & 0,474 & 0,554 & Valid & 0,547 & 0,574 & Drop \\
\hline 56 & & C56 & 0,754 & 0,881 & Valid & 0,753 & 0,790 & Valid \\
\hline 57 & & C57 & 0,513 & 0,599 & Valid & 0,735 & 0,771 & Valid \\
\hline
\end{tabular}




\begin{tabular}{|c|c|c|c|c|c|c|c|c|}
\hline No & Dimensions & Items & $\begin{array}{l}\text { Loading } \\
\text { Factor } \\
\text { Trial } 1\end{array}$ & $\begin{array}{l}\text { Attenuation } \\
\text { Effect }\end{array}$ & Status & $\begin{array}{c}\text { Loading } \\
\text { Factor } \\
\text { Trial } 2\end{array}$ & $\begin{array}{l}\text { Attenuation } \\
\text { Effect }\end{array}$ & Status \\
\hline 58 & & C58 & 0,695 & 0,812 & Valid & 0,662 & 0,695 & Valid \\
\hline 59 & & C59 & 0,643 & 0,751 & Valid & 0,624 & 0,655 & Valid \\
\hline 60 & & $\mathrm{C} 60$ & 0,691 & 0,807 & Valid & 0,453 & 0,475 & Valid \\
\hline 61 & & C61 & 0,7 & 0,818 & Valid & 0,655 & 0,687 & Valid \\
\hline 62 & & C62 & 0,461 & 0,538 & Valid & - & \#VALUE! & - \\
\hline 63 & & C63 & 0,145 & 0,169 & Valid & - & \#VALUE! & - \\
\hline 64 & & C64 & 0,53 & 0,619 & Valid & - & \#VALUE! & - \\
\hline
\end{tabular}




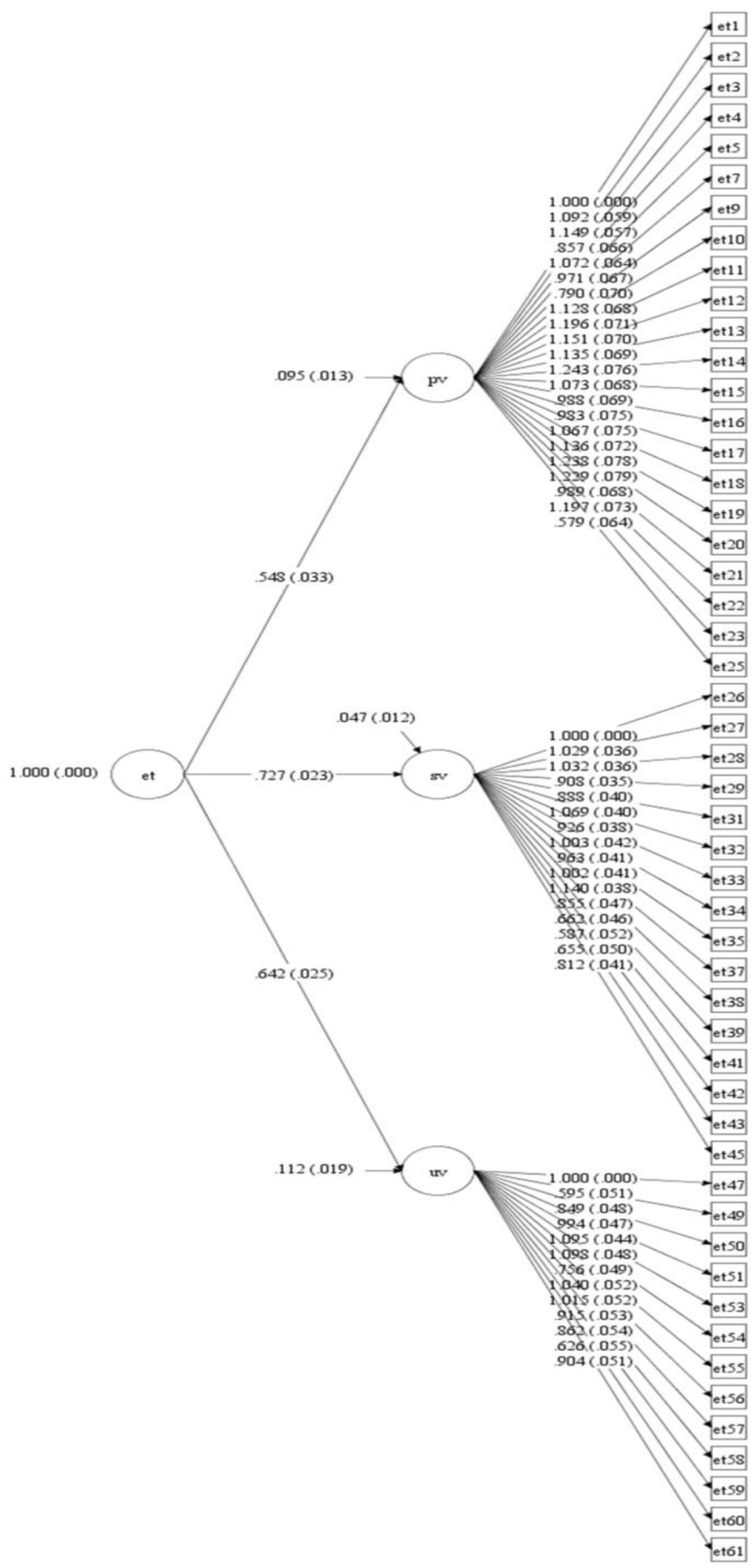

Figure 1. Diagram of CFA 
The results of the Construct Analysis of the Model fit for the first and second stages trial are shown in the table below:

Table 4. The Results of The Construct Analysis of The Model

\begin{tabular}{|c|c|c|c|c|}
\hline & Step & Item Total & Model Match Requirements & Estimated Results \\
\hline & Analysis & 61 & Chi-square & $5476.354^{*}$ \\
\hline \multirow[t]{4}{*}{1} & & & Df & 1766 \\
\hline & & & P-value & 0.0000 \\
\hline & & & RMSEA & 0.069 \\
\hline & & & CFI & 0.855 \\
\hline & Analysis & 51 & Chi-square & $3443.779 *$ \\
\hline \multirow[t]{4}{*}{2} & & & Df & 1221 \\
\hline & & & P-value & 0.0000 \\
\hline & & & RMSEA & 0.065 \\
\hline & & & CFI & 0.908 \\
\hline
\end{tabular}

The following table below is the final distribution of the Teacher Profession Ethics instrument item numbers,

Table 5. Distribution of Final Teacher Professional Ethics Instrument Items Number

\begin{tabular}{llc}
\hline \multicolumn{1}{c}{ Dimensions } & \multicolumn{1}{c}{ New Item Number } & Total \\
\hline Personal Value & $1,2,3,4,5,6,7,8,9,10,11$, & 22 \\
& $12,13,14,15,16,17,18,19$, & \\
& $20,21,22$ & 16 \\
\hline Social Value & $23,24,25,26,27,28,29,30$, & 13 \\
& $31,32,33,34,35,36,37,38$ & \\
\hline Universal Value & $39,40,41,42,43,44,45,46$, & 51 \\
& $47,48,49,50,51$ & \\
\hline Total & & \\
\hline
\end{tabular}

\section{Guidelines for Using Instruments}

The instrument for teachers' professional ethics is equipped with guidelines for its use. It is intended that users can interpret and interpret the results of respondents' answers. This teacher professional ethics instrument consists of 51 items with the highest score of 5 answer choices and the lowest score of 1 for each item. The interpretation of the results of the assessment carried out on the professional ethics of elementary school teachers in Indonesia uses a level categorization model by placing teachers in 3 (three) levels of professional ethics, namely very good, good, and bad professional ethics, which the benchmark uses the theoretical average benchmark $(\mu)$ and theoretical standard deviation (ó), For data interpretation of the results of measuring teacher professional ethics, the range of interpretations is presented in the following table,

Table 6. Scores Range and Interpretation of teacher professional ethics

\begin{tabular}{cc}
\hline Score and Range & Interpretation \\
\hline$X<(\mu$-ó $)$ & Bad professional ethics \\
\hline$(\mu-o ́) \leq X<(\mu+1$ ó $)$ & Good professional ethics \\
\hline$X \geq(\mu+1$ ó $)$ & Very Good professional ethics \\
\hline
\end{tabular}

The table above is the reference table for interpreting the professional ethics assessment of elementary school teachers. The teacher professional ethics score was interpreted by interpreting the overall teacher professional ethics score (dimensions), then confirmed by categorization through the teacher professional ethics items' total score.

\section{DISCUSSION}

Research on the development of measuring instruments for teacher professional ethics has been widely carried out. However, there is still no development of a specific instrument for measuring 
Indonesia's teaching profession's ethics. Several previous studies discuss the ethics of the teaching profession, among others, Husu (2003), who researched to interpret and translate teachers' understanding of the language they use. This translation provides concrete expressions to be interpreted in their daily lives. This study presents how to view and interpret pedagogical practice that will help teachers understand their professional practice. Also, Johnson (2010) researched Applied Ethics as a Foundation in Early Childhood Teacher Education: Exploring the Connections and Possibilities. This study helps early childhood teachers in developing a strong professional identity for teachers. Forster (2012) researched Codes of Ethics in Australian Education: Towards a National Perspective. In this article, we offer thoughts to review the purpose of the code of conduct in Australia as an instrument that profoundly influences teacher morality and has significant educational implications. In 2012, Elina Kuusisto, Kirsi Tiri, and Inkeri Rissanen researched Finnish Teachers' Ethical Sensitivity. This research was conducted in order to determine the sensitivity of teachers in Finland. In 2013, Yael Fisher researched Exploration of Value: Israeli Teachers' Professional Ethics. This study explores the ethical values of the Israeli teacher profession using Facet Theory. Develop instruments to be the basis for building a code of ethics for teachers in Israel. In 2016, Danijela Blanusa Troselj and Zeljka Ivkovic researched Building the Profession: Professional Ethics and Preschool Teacher's Education. Teacher professional ethics is important in supporting the education system's success, so this research needs to be done.

Based on the literature review results that have been done, there are three main dimensions defined for teachers' professional ethics. These dimensions are social value, personal value, and universal value (Fisher 2013; TAC, 1998). Based on these dimensions, an elementary school teacher professional ethics test instrument was developed based on Indonesia's conditions.

After several CFA analysis stages with M-Plus, a teacher professional ethics instrument test was obtained, which consisted of 51 items spread over three dimensions. Items have met the criteria for validity and reliability to measure teacher professional ethics. The personal value dimension consists of 22 items, the social value dimension consists of 16 items, and the Universal value dimension consists of 13 items. It was in line with Fisher's research, which found that the teacher professional ethics consisted of those three dimensions.

Based on the model fit test results, the trial's two stages had met the requirements, and the model fit with the data was declared. The first trial results of the analysis of the latent variable construction dimensions have met the predetermined target, namely $\mathrm{t}$-value $\geq 1.96$. And the results of the description of the Table 4 above obtained a fit factor model with Chi-square $=3417.231 *, \mathrm{df}=1949, \mathrm{P}$-value $=0.0000$, RMSEA $=0.065, \mathrm{CFI}=0.879$, stating that this model is fit with the data. In the second phase of testing, the latent variable constructs' analysis has met the predetermined target, namely the t-value $\geq$ of 1.96 . The results of the information in Table 4 above obtained a fit factor model with Chi-square $=3443,799 *, \mathrm{df}=$ 1221 , P-value $=0.0000$, RMSEA $=0.065, \mathrm{CFI}=0.908$, stating that this model is fit with the data. The results of this trial's two stages indicate that the test instrument that has been made measures a constructed variable, namely teacher profession ethics. From the second stage analysis results, it is concluded that all the items tested in the second stage, as many as 51 items, have met the requirements and are considered to have a fit model, and their validity has been tested empirically.

Furthermore, the attenuation test is carried out to purify an item's validity value and check the low validity and reliability. Is the low validity and reliability due to invalid items or other factors? The results of the attenuation effect on each item of teacher profession ethics proved to be significantly increased, meaning that other factors influenced it.

An elementary school teacher professional ethics instrument that has met the validity and reliability criteria is expected to measure professional ethics, even for prospective teachers. It was expected to become a measure to determine a set of duties or obligations that were good and clear enough to be followed and produced the desired ethical behavior as stated by S. Food (Todd, 2001). It also could be a step to prevent criminal acts and harassment in schools, especially at the elementary school level. Considering the many cases of harassment that have occurred at the elementary school level.

Warnick (2011) stated that professional ethics is currently a neglected topic in teacher education programs. This test can be one of the schools' policies in detecting teachers' tendency to commit acts that violate the professional code of ethics. So that if it can be detected early, the teacher will be able to guide the teacher. This is by the statement Sánchez (2001), which states that schools need to be aware of policies to protect students from sexual harassment by teachers or other students. The possibility of violating the code of ethics by teachers can be detected early. 
A limitation in this study is the test instrument developed specifically for elementary school teachers. There needs to be further research that develops teacher professional ethics test instruments for other levels such as high school or other levels.

\section{CONCLUSIONS}

This study aims to develop and validate an instrument of teacher professional ethics test for elementary school teachers in Indonesia. Based on the results of the analysis that has been carried out, it can be concluded that the 51 items that have been developed meet the validity and reliability criteria of the test and can measure defined constructs properly. This test can then be used in measuring the professional ethics of primary school teachers, especially in Indonesia.

\section{REFERENCES}

Ashraf, N. S. dan H. (2015). The Relationship Between Iranian EFL Teacher's Commitment to Professional Ethics and their Student's Self- Esteem. Mediterranean Journal of Social Sciences MCSER Publishing, Rome- Italy, 6(5), 135.

Astuti, P. (2012). Etika Profesi sebagai Upaya Preventif Untuk meminimalisasi pelanggaran Hukum yang dilakukan oleh guru. Jurnal UNS, 6(3), 183.

Banks, S. (2003). From oaths to rulebooks: a critical examination of codes of ethics for the social professions. European Journal of Social Work, 6(2), 133-144.

Blanusa, T. D., \& Ivkovic, Z. (2016). Building the Profession: Professional Ethics and Preschool Teacher's Education. Scientific Paper Prihvaceno, 1(9), 403-421.

Borg, W.R. \& Gall, M.D. Gall. (1983). Educational Research: An Introduction, Fifth Edition. New York: Longman.

Campbell, E. (2008). Teaching ethically as a moral condition of professionalism. In L. Nucci \& D. Narváez (Eds.), The international handbook of moral and character education (pp. 601-617). New York: Routledge.

Carr, D. (2000). Professionalism and Ethics in Teaching. London/ New York: Routledge, Taylor and Francis Group.

Carr, D. (2010). Professional Education and Professional Ethics. Journal of Applied Philosophy, 16(1), 3346.

Carr, D., \& London, J. (2000). "Teachers and Schools as Agencies of Values Education: Reflections on Teachers' Perceptions. Part I: The Role of the Teacher.". Journal of Beliefs and Values, 19, 165.

Corney, G., Corney, M. S., \& Callanan, P. (1998). Issues and ethics in the helping professions. U.S.A.: Brooks /Cole.

Curtis, D. M. (2006). Everything I Wanted To Know About Teaching Law School I Learned From Being a Kindergarten Teacher: Ethics in the Law School Classroom. Brigham Young University Education and Law Journal, 455.

Dewey, J. (1909). Moral principles in education. Boston: Houghton Mifflin.

Fisher, Y. (2013a). Exploration of Value: Israeli Teacher's Professional Ethics, 2013. h. 297-315. Science+ Business Media Dordrecht, 297-315.

Fisher, Y. (2013c). Exploration of values: Israeli teachers' professional ethics. Social Psychology of Education, 16(2), 297-315. https://doi.org/10.1007/s11218-013-9211-0

Forster, D. J. (2012). Codes of Ethics in Australian Education: Towards a National Perspective, Australian. Australian Journal of Teacher Education 37, 37(9).

Gable, Robert k., \& Wolf, M. B. (1993). Instrument Development in Effective Domain. Boston: Kluwer Academic Publisher.

Haladyna, T. M. (2004). Developing and Validating Multiple-choice Test Item. New Jersey: Lawrence Elbaurm Associate Publisher.

Hill, A. L. (2004). Ethical Analysis in Counseling: A Case for the Narrative ethics, moral, and Virtue Ethics. Counseling and Value, 131.

Husu, J. (2003). constructing Ethical Representations From the Teacher's Pedagogical Practice: A Case of Prolonged Reflection, Interchange. Kluwer Academic Publishers. Printed in the Netherlands., 34(1), 121.

Johnson, T. G. (2011). Applied Ethics as a Foundation in Early Childhood Teacher Education: Exploring the Connections and Possibilities. Early Childhood Educ J, 38, 449-456.

Izraeli, D., Zohar, N. (Eds.) (2002). Ethics and social responsibility: Israeli insights. Tel-Aviv: Cherikover. (in Hebrew).

Kasher, A. (1993). What is Professional Ethics? In Ethical issues in therapeutic professions and psychological 
therapy. (\& G. W. (eds. . G. Shefler, Y. Achmon, Ed.) (Ethical is). Israel: Y.I. Magnes Publications.

Kompas, 30 Juli 2012. (2012). Kekerasan di Sekolah pernah dialami 87,6\% siswa. Dan A.B.C. Australia, 20 Desember 2012, kekerasan di Sekolah meningkat, Mendesak Kebijakan Sekolah Ramah Anak. Jakarta.

Kuusisto, Elina, K. T. and I. R. (2012). Finnish Teachers' Ethical Sensitivity. Education Research International, 1-10.

Kuusisto, E., Tirri, K., \& Rissanen, I. (2012). Finnish Teachers' Ethical Sensitivity. Educational Research International, 2012, 10. https://doi.org/10.1155/2012/351879.

Mardapi, D. (2012). Pengukuran, Penilaian dan Evaluasi Pendidikan. Yogyakarta: Nuha Medika.

Melgosa, J. (2012). Professional Ethics for Administrator. Journal of Adventist Education Professional, $66(3), 42$.

Moss Curtis, D. (2006). Everything I wanted to know about teaching law school, I learned from being a kindergarten teacher: ethics in the law school classroom. B.Y.U. Education and Law Journal, 455498.

Peters, R. S. (1966). Ethics and education. London: Allen \& Unwin.

Reyad, A. H. A. (2014). The Degree of Teacher Commitment to the Code of Conduct and Ethics of Profession as Perceived by Schools Principals and Educational Supervisors in Karak Governorate, European Scientific Journal, 10(April).

Rowland, (2009). Unethical behavior, academic misconduct, \&incivility: Does it occur in adult education classrooms? Doctoral Dissertation, Ohio State University). Retrieved from http://www.adulterc.org/Procedings/2009/Proceedings/rowland.pdf, 2009,

Sánchez, E., Robertson, T. R., Lewis, C. M., Rosenbluth, B., Bohman, T., \& Casey, D. M. (2001). Preventing bullying and sexual harassment in elementary schools: The Expect Respect model. Journal of Emotional Abuse, 2(2-3), 157-180.

Santoso, S. (2015). Statistika Multivariate. Jakarta: Elex Media Komputindo Gramedia.

Schwartz, S. H. (1992). Universals in the content and structure of values: Theoretical advances and empirical test in 20 countries. Advances in experimental social psychology (Vol. 25). San Diego, CA: Academic Press. https://doi.org/10.20595/jjbf.19.0_3.

Schwartz, S. H. (1994). Are there universal aspects in the structure and contents of human values? Journal of Social, 50(4), 19-45.

Shapiro, J. P., \& Stefkovich, J. A. (2011). Ethical leadership and decision making in education: Applying theoretical perspectives to complex dilemmas (Vol. 3). New York: Routledge of the Taylor\& Francis Group.

Susetyo, B. (2015). Prosedur Penyusunan dan Analisis Tes untuk Penilaian Hasil Belajar Bidang Kognitif. Bandung: Refika Aditama.

Tex. Admin. Code (TAC). (1998). Code of Ethics and Standard Practices for Texas Teacher. Texas.

Thompson, M. D. dan J. R. (2015). The Teaching of the Code of Ethics and Standard Practices for Texas Educator Preparation Programs. NCPEA Internationa Journal of Education Leadership Preparation, $10,82-95$.

Tirri, K. (2010). "Teachers' Values Underlying their Professional Ethics," in International Handbook on Values Education and Student Well-Being, Springer, New York, NY, USA.

Tirri, K., Husu, J., \& Kansanen, P. (1999). The Epistemological Stance between the Knower and the Known. Teaching and Teacher Education, 15(8), 911-922.

Todd, S. (2001). "Bringing more than I contain, Ethics, Curriculum and the Pedagogical Demand for Altered Egos. Journal of Curriculum Studies, 436.

Torda, A. (2004). Acceptable behavior. Training Agenda, 12(3), 15-16.

Troselj, D. B., \& Ivkovic, Z. (2016). Building the Profession: Professional Ethics and Preschool Teacher's Education. Izvorni znanstveni Clanak/ Original Scientific Paper Prihvaceno, 1(9), 403-421.

Umar, Y. (2014). Confirmatory factor analysis. Jakarta: Fakultas Psikologi UIN Jakarta.

Urbanc, K. (2009). Etika I Vrijednosti u Socijalnom Radu. Ljetopis Socijalnog Rada, (Vol. 8).

Vivanews. (2012). Tingkatkan Mutu Pendidikan, Kode Etik Guru Berlaku Tahun 2013.

Vockell, E. L. (1983). Educational Research. New York: Mac Millan Publishing Co., Inc.

Waller, W. (1932). The sociology of teaching. New York: Wiley

Warnick, B. R., \& Silverman, S. K. (2011). A framework for professional ethics courses in teacher education. Journal of Teacher Education, 62(3), 273-285.

William, M., \& Burden, R. (2004). Psychology of Language Teachers: A Social Constructivist Approach. Emst Klett Sprachen. 